\title{
スーパーコネクトレベルの微細配線パターンに対する 電気的信頼性の交流インピーダンス法による評価
}

\author{
佐藤 誠 ${ }^{*}$, 吉原 佐知雄 ${ }^{*}$, 白整 高史 ${ }^{*}$
}

\section{Evaluation of Electric Reliability for Super Connect Level Refined Wiring Pattern by Means of AC Impedance Method}

Makoto SATO* ${ }^{*}$, Sachio YOSHIHARA* and Takashi SHIRAKASHI*

\footnotetext{
*宇都宮大学大学院工学研究科エネルギー環境科学専攻（テ321-8585 栃木県宇都宮市陽東 7-1-2)

*Department of Energy and Environmental Science, Graduate School of Engineering, Utsunomiya University (7-1-2 Yoto, Utsunomiya-shi, Tochigi 321-8585)
}

\begin{abstract}
We have fabricated copper refined wiring pattern of super connect level on polyimide. We prepared it by means of semi-additive process, which enabled flat connection between copper pattern and polyimde. The aim of this paper is the evaluation of durability for ionic migration on above newly developed sample under high temperature and high humidity $\left(85^{\circ} \mathrm{C}, 85 \% \mathrm{RH}\right)$. We adopted mainly AC impedance method for the analysis of ionic migration. In consequence, incidence of ionic migration was confirmed. By measuring charge transfer resistance by this method, incidence of ionic migration and initial defects of electrodes could be detectable.
\end{abstract}

Key Words: Super Connect, Ionic Migration, Copper, AC Impedance Method, Polyimide

\section{1. 緒 言}

近年, 電子機器の小型化, 高密度実装などによりプリン 卜配線板における導体間がますます微細化している。現在 では，半導体 IC とプリント配線板実装の技術差を埋める スーパーコネクト（デザインルール $10 \mu \mathrm{m}$ 前後の配線・接 続技術）と呼ばれる新技術体系が注目されており，開発が 進められている。また一方では, 電子機器の用途が拡大し ており，それに伴いプリント配線板の実使用環境が，温度 や湿度の影響を受けやすい㛜しい環境にも及んでいる。

このような傾向が進展するにつれて，プリント配線板の 絶縁信頼性, 特にイオンマイグレーション（以下マイグ レーションと略す）による絶縁劣化故障が発生しやすくな ることが知られており重要な問題となっている。

マイグレーションとは, 電気化学的腐食現象の 1 つであ り，プリント配線板など隣接あるいは対向する電極間に吸 湿や結露などにより水分が付着した状態で電圧が印加され ると, 一方の金属電極から他方の金属電極へ向かって金属 イオンが移行し, 金属または化合物が析出し, 電極間が短 絡する現象である。そのため, 絶縁信頼性を得るうえでマ イグレーション性や反応機構を解明することが必要である。

従来のマイグレーション性評価には，金属または金属酸 化物の析出に伴う電極間短絡による絶縁抵抗の低下に注目 し，短絡故障時間を比較する方法を利用していた。しか し，これらの方法では，マイグレーション発生から成長の 過程における反応機構の解析は不可能である。
そこで著者らは，マイグレーションの成長過程における 反応機構の解析法として交流インピーダンス法を適用した。 交流インピーダンス法はその場測定が可能であり, 電極界 面の反応機構解析法として有効な手法である ${ }^{1)}$ 。

本報告では，スーパーコネクトレベルの銅の微細配線パ ターンをポリイミド上に形成し，このような基板に対して 高温高湿下 $\left(85^{\circ} \mathrm{C}, 85 \% \mathrm{RH}\right)$ における耐マイグレーション性 を交流インピーダンス法により評価した。また，析出物の 解析にはSEM, EDXを用いた。なお，基板の作製には高周 波特性を考慮し, 銅パターンと下地層とのフラットな接続 を可能にするセミアディティブ法を用いている。

\section{2. 試料および実験方法}

試料には，厚さ $25 \mu \mathrm{m}$ のポリイミド上に銅の櫛型配線パ ターンを施した基板を用いた。その櫛型配線の電極長さは 1, 2,3 mm と作製されており，さらにそれぞれにL/S (Line \& Space)が 4/6, 8/12, 12/16 $\mu \mathrm{m}$ と作製されている。Fig. 1 に試 料の構造を示す。Fig. 1 に示すように，合計 9 種の櫛型電極 を持つ。

実験方法は以下の通りである。イオン交換蒸留水および エタノールで洗浄した試料を小型環境試験器（エスペック 社製）内に置き, 試験器内の温度を $85^{\circ} \mathrm{C}$, 湿度を $85 \% \mathrm{RH}$ まで上昇させた。なお，その上昇過程は，基板に結露が起 きないように温度上昇を先行させ，その後湿度上昇を行っ た。試験器内の温度および湿度が設定値に達した後, ポテ ンショスタットより試料に直流電圧 $5.0 \mathrm{~V}$ を印加し, さらに 


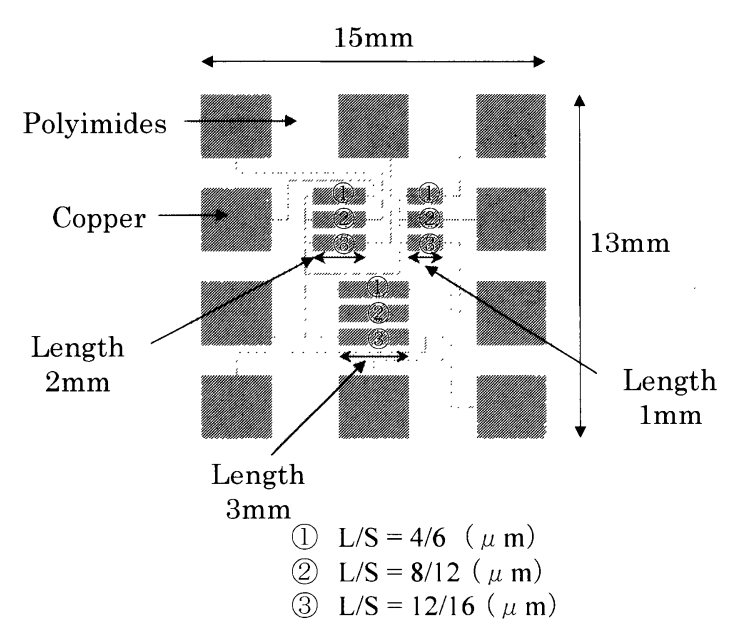

Fig. 1 Structure of test sample

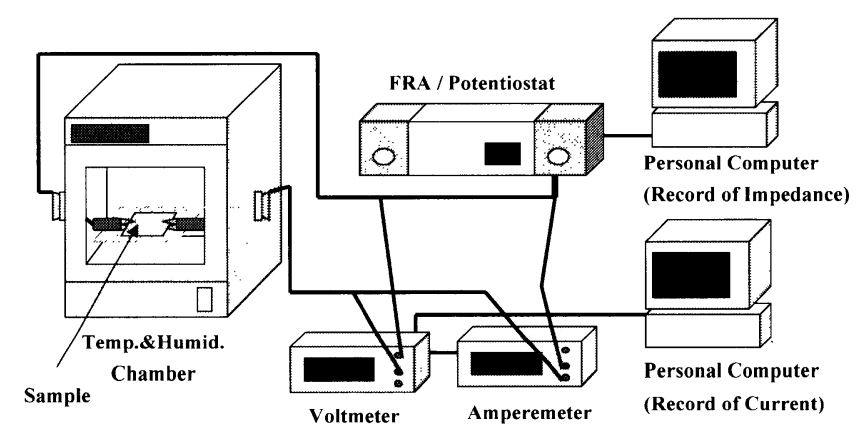

Fig. 2 Testing device

振幅 $0.35 \mathrm{~V}$, 周波数領域 $10 \mathrm{kHz} \sim 1 \mathrm{~Hz}$ の交流電圧を重畳し, そのときの電流值およびインピーダンスの経時変化を測定 した。実験装置図をFig. 2 に示す。測定時間は 25 時間，イ ンピーダンスの測定間隔は 30 分とした。インピーダンスは 周波数応答解析装置：FRA（Frequency Response Analyzer; Eco Chemie BV 社製）を用いて测定し, Cole-Cole プロット を作成し処理した。また, 測定前後の試料表面を電解放射 型走査電子顕微鏡：FE-SEM（Field Emission Scanning Electron Microscope; 日立製作所製）およびエネルギ分散型 X 線分光法：EDX（Energy Dispersive X-Ray Spectroscopy; 日立製作所製）により解析した。

以上の操作を条件が異なる 9 種の櫛型電極に対して行い, さらに試料が高温高湿条件下に 25 時間暴露される時間を 1 回とし，その回数を 1 回 (約 25 時間), 2 回（約 50 時間), 3 回（約 75 時間）亡変化させて耐マイグレーション性の比 較および解析を行った。なお， 1,2,3回時すべてについて， 電圧印加時間は 25 時間となっており，1回時においては高 温高湿条件と電圧印加が 25 時間同時に負荷されている。 2 回時の場合は, 最初の高温高湿条件下に 25 時間暴露され るときは, 電圧印加は行っておらず，次の高温高湿条件下 に25 時間暴露されるときのみ電圧印加が行われている。 3 回時も同様に, 最後の高温高湿条件下に 25 時間暴露され るときのみ電圧印加が行われており，その前の 50 時間

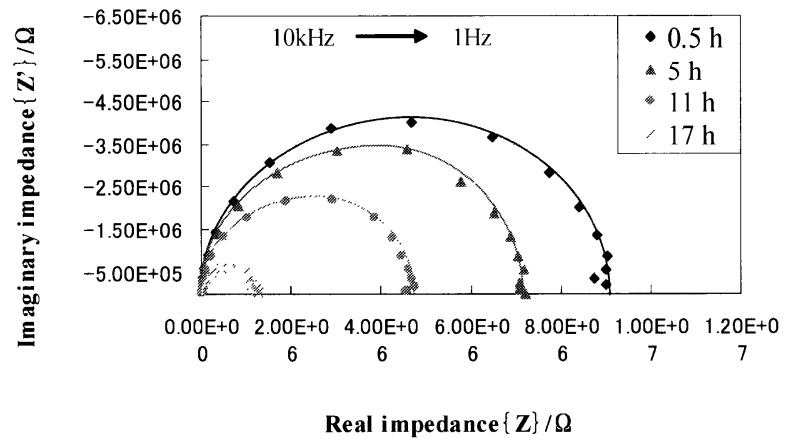

Fig. 3 Example of Cole-Cole plots (Case of migration: electrode length $1 \mathrm{~mm}, L / S=4 / 6 \mu \mathrm{m}, 2$ cycle)

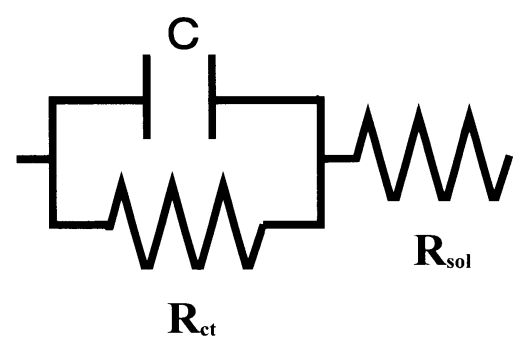

Fig. 4 Equivalent circuit

$(25 \times 2)$ は，電圧印加は行っていない。このような電圧印加 なしの時間を設けたのは，腐食の影響を見るためである。

\section{3. 実験結果および検討}

\section{1 インピーダンス測定結果}

Fig. 3 にインピーダンス測定から作成したCole-Cole プロッ トの一例を示す。ここでは, その変化がわかりやすいマイ グレーションが測定時間内に発生した場合について示す。 また, 得られたCole-Cole プロットから推定される等価回路 をFig. 4 に示す。Fig. 3 のように容量性半円が第 4 象限に確 認され，判別しにくいが溶液抵抗も確認された。この様子 は電極の条件によらず同様な結果が得られた。マイグレー ションが発生した場合は，その半円が短絡した時間に近づ くにつれて縮小していく様子が確認された。マイグレー ションが発生しなかった場合は，半円の大きさは初期状態 から変化せず一定であった。そして, 半円の直径より電 荷移動抵抗 $R_{\mathrm{ct}}$ (Charge Transfer Resistance), 半円の頂点 の角周波数 $\left(\omega_{\max }\right)$ と $R_{\mathrm{ct}}$ より界面容量 $C$ (Capacitance $=$ $\left.1 /\left[\omega_{\max } \cdot R_{\mathrm{ct}}\right]\right)$ を求めた ${ }^{2), 3)}$ 。このようにして, $R_{\mathrm{ct}}$ および $C の$ 経時変化を異なる電極条件ごとに求めた。その結果は 3.2 節で示す。

\section{2 電流値および $R_{\mathrm{ct}}$ の経時変化}

\section{2 .1 電極長さ $1 \mathrm{~mm}$ の場合}

電極長さ $1 \mathrm{~mm}$ の条件の各 $L / S$ の電流值変化から, マイグ レーションが発生したと考えられるのは $L / S=4 / 6 \mu \mathrm{m}$ のき のみであった。Fig. 5 に電極長さ $1 \mathrm{~mm}, L / S=4 / 6 \mu \mathrm{m}$ 時の電 流值の経時変化を示す。 


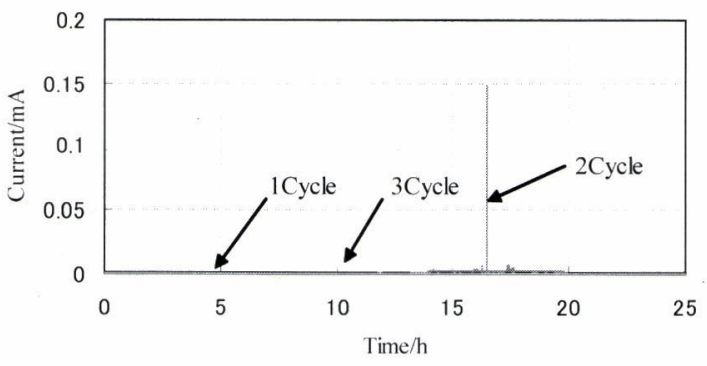

Fig. 5 Change in current (Electrode length $1 \mathrm{~mm}$, $L / S=4 / 6 \mu \mathrm{m}$ )

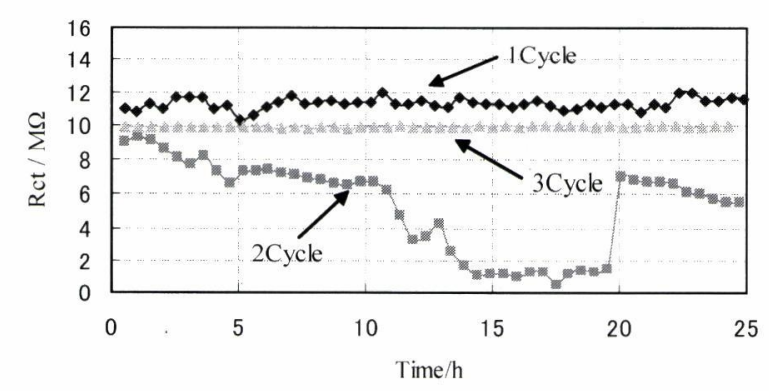

Fig. 6 Change of charge transfer resistance (Electrode length $1 \mathrm{~mm}, L / S=4 / 6 \mu \mathrm{m}$ )

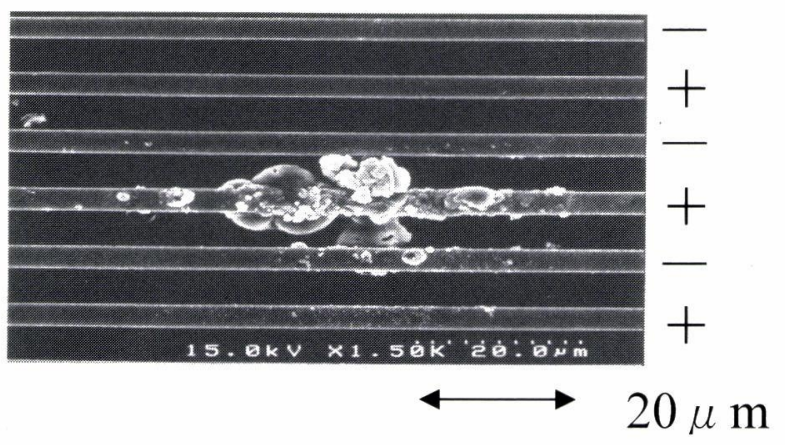

Fig. 7 SEM photographs (Electrode length $1 \mathrm{~mm}$, $L / S=4 / 6 \mu \mathrm{m}, 2$ cycle)

電流值の急激な上昇は，その時間においてマイグレー ションにより電極間が短絡したことを示す。Fig. 5からマ イグレーションが発生したと考えられるのは, 高温高湿条 件に 2 回暴露されるときのみであった。また, Fig. 6 に電極 長さ $1 \mathrm{~mm}, L / S=4 / 6 \mu \mathrm{m}$ 時の $R_{\mathrm{ct}}$ の経時変化を示す。電流値 の経時変化からマイグレーションが発生しなかったと考え られる場合は， $R_{\mathrm{ct}}$ は終始ほぼ一定の值を保っていたので, やはり電極界面に大きな変化がなかったと考えられる。一 方, マイグレーションが発生したと考えられる場合は, そ の発生時間（約 16.5 時間）に至るまでに, 徐々に $R_{\mathrm{ct}}$ 值が 減少していく様子が見られた。そこで，電極に変化が見ら れるかどうかをSEMにより観察した。その結果，やはり高 温高湿条件に 2 回暴露される場合において析出物が確認さ れたので，その様子をFig. 7 に示す。電流值の変化が瞬間 的であることから析出物が焼き切れたことを予想したが, アノード(+)側から析出物が成長しているので, 酸化物之

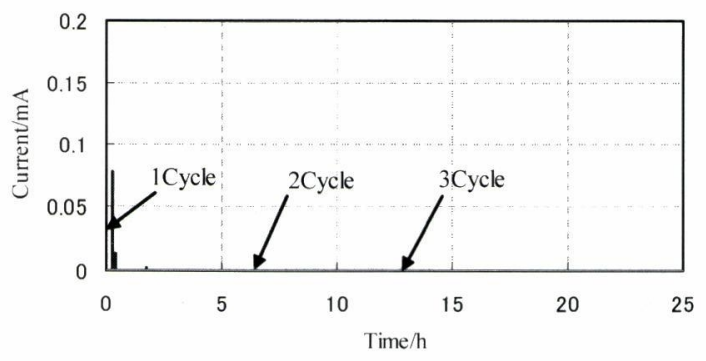

Fig. 8 Change in current (Electrode length $2 \mathrm{~mm}$, $L / S=4 / 6 \mu \mathrm{m}$ )

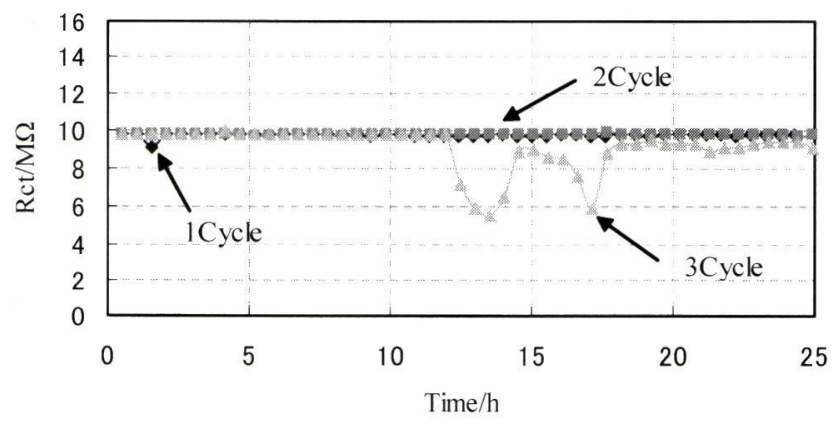

Fig. 9 Change of charge transfer resistance (Electrode length $2 \mathrm{~mm}, L / S=4 / 6 \mu \mathrm{m}$ )

考えられる析出物が緻密に成長していく形態をとっている ものと考えられる。

$L / S=8 / 12,12 / 16 \mu \mathrm{m}$ の場合は, マイグレーションは発生 せず， $R_{\mathrm{ct}}$ はFig. 6 の 1, 3 回とほぼ同じ值を示しており安定 していた。

\section{2 .2 電極長さ $2 \mathrm{~mm}$ の場合}

電極長さ $2 \mathrm{~mm}$ の条件の各 $L / S$ の電流値変化から, マイグ レーションが発生したと考えられるのは, やはり $L / S=$ $4 / 6 \mu \mathrm{m}$ のさきのだった。Fig. 8 に電極長さ $2 \mathrm{~mm}, L / S=$ $4 / 6 \mu \mathrm{m}$ 時の電流值の経時変化を示す。Fig. 8からマイグレー ションが発生したと考えられるのは, 高温高湿条件に 1 回 暴露されるときのみであった。また，Fig. 9 に電極長さ $2 \mathrm{~mm}, L / S=4 / 6 \mu \mathrm{m}$ 時の $R_{\mathrm{ct}}$ の経時変化を示す。電流值と $R_{\mathrm{ct}}$ の経時変化を照らし合わせて検討をすると, Fig. 9 から電 流值の上昇が見られた高温高湿条件に 1 回暴露される場合 において， $R_{\mathrm{ct}}$ の変化が見られなかった。電流值が急上昇し ている点は約 0.3 時間のときであり, インピーダンス測定 前に安定に至っているため, インピーダンスには影響が見 られなくなってしまったと考えられる。インピーダンスの 測定間隔をさらに短くすることにより，変化を追従できる と考元られる。一方, Fig. 9から電流值の上昇が見られな かった高温高湿条件に 3 回暴露される場合において, $R_{\mathrm{ct}}$ の 変化が見られる。実際, 高温高湿条件に 3 回暴露される場 合の測定後の基板表面のSEM像からは, 微量な析出物が 確認された。その結果をFig. 10 に示す。その際のわずかな 電極界面の変化が $R_{\mathrm{ct}}$ 值に影響を及ぼしたと考えられる。こ のような析出が続くと, 今回の測定時間範囲内では電流值 


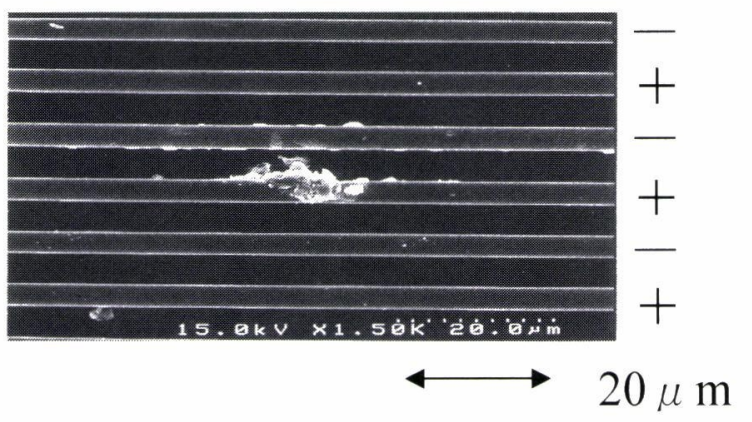

Fig. 10 SEM photographs (Electrode length $2 \mathrm{~mm}$, $L / S=4 / 6 \mu \mathrm{m}, 3$ cycle)

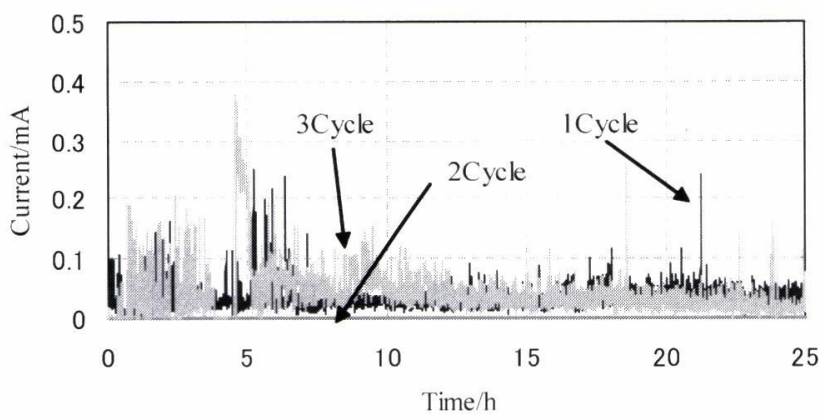

Fig. 11 Change in current (Electrode length $3 \mathrm{~mm}$, $L / S=4 / 6 \mu \mathrm{m}$ )

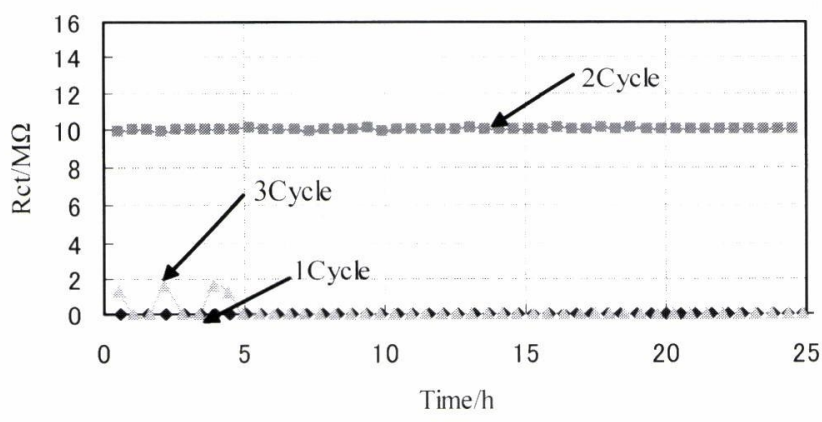

Fig. 12 Change of charge transfer resistance (Electrode length $3 \mathrm{~mm}, L / S=4 / 6 \mu \mathrm{m}$ )

の急激な上昇は見られなかったが，より長い時間領域にお いて変化が見られるむのと考えられる。

$L / S=8 / 12,12 / 16 \mu \mathrm{m}$ の場合は, 3.2 .1 項同様マイグレー ションは発生せず， $R_{\mathrm{ct}}$ は安定していた。

\section{2 .3 電極長さ $3 \mathrm{~mm}$ の場合}

電極長さ $3 \mathrm{~mm}$ の条件の各 $L / S$ の電流值変化から, マイ グレーションが発生したと考えられるのは, やはり $L / S=4 / 6 \mu \mathrm{m}$ のきのみだった。Fig. 11 に電極長さ $3 \mathrm{~mm}$, $L / S=4 / 6 \mu \mathrm{m}$ 時の電流值の経時変化を示す。Fig. 11 からマイ グレーションが発生したと考えられるのは, 高温高湿条件 に 1 回および 3 回暴露される場合であった。Fig. 11 からわ かるように，この場合に拈いては電流值の上昇は終始見ら れ，マイグレーションの度合いが激しいことが予想される。 また, Fig. 12 に電極長さ $3 \mathrm{~mm}, L / S=4 / 6 \mu \mathrm{m}$ 時の $R_{\mathrm{ct}}$ の経時 変化を示す。マイグレーションは測定開始直後に発生した

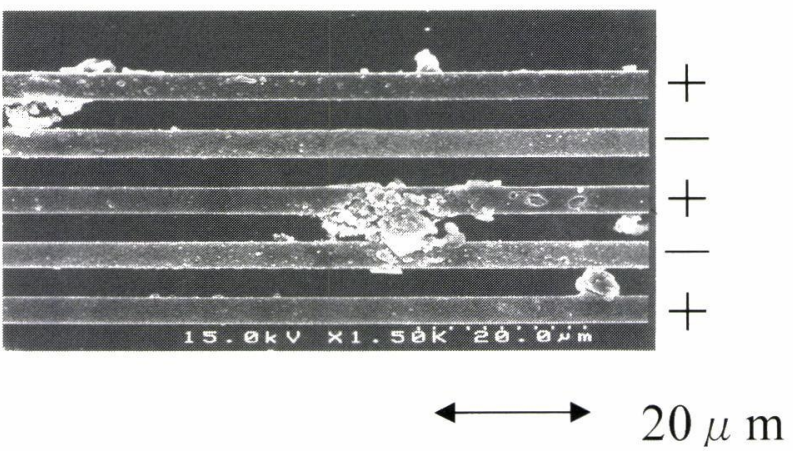

Fig. 13 SEM photographs (Electrode length $3 \mathrm{~mm}$, $L / S=4 / 6 \mu \mathrm{m}, 1$ cycle)

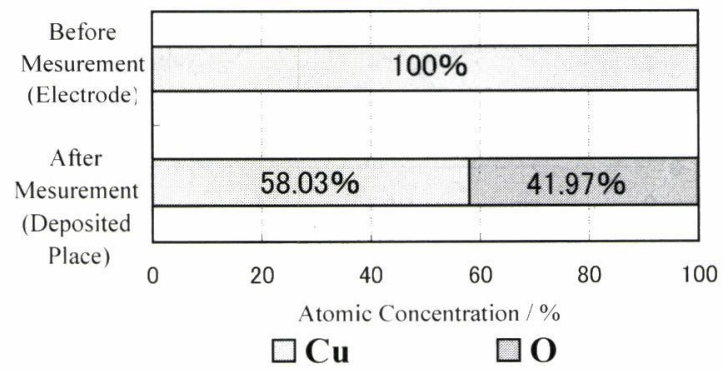

Fig. 14 Composition analysis by EDX

ため，インピーダンスは始めから一点に収束していた。マ イグレーションが発生したと考えられる高温高湿条件に1 回暴露される場合の SEM 像を Fig. 13 に示す。Fig. 13 から やはり大きな析出物が確認され, 電極間が完全に短絡して いる様子がわかった。一方，高温高湿条件に 2 回暴露され る場合のみ $R_{\mathrm{ct}}$ は終始ほぼ一定の值を保っていたので, 電 極界面が安定していたと考えられる。

そして $, L / S=8 / 12,12 / 16 \mu \mathrm{m}$ の場合は, これまで同様マ イグレーションは発生せず, $R_{\mathrm{ct}}$ は安定していた。

3.3 EDXによる析出物の解析

Fig. 14 にEDXによる析出物の元素分析結果を示す。Fig. 14 から，析出物には銅の他に酸素が多く含まれることわか り，主成分は酸化銅 $\mathrm{CuO}$ であると考えられる。これは，先 に示したアノードから成長していることと符合する。

\section{4. まとめ}

スーパーコネクトレベルの微細配線パターンに対してマ イグレーション評価を行った結果, $L / S=4 / 6 \mu \mathrm{m}$ では 25 時 間以内に何度かマイグレーションの発生が確認された。ま

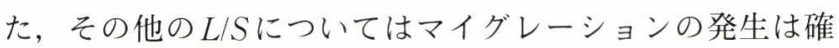
認されなかったが，より長時間の測定では発生する可能性 がある。今回は, 電極が露出した状態の試料を用いたので, マイグレーションの発生を防止する工夫が必要と考えられ る。

高温高湿条件下，櫛型基板を用いるマイグレーション評 価に交流インピーダンス法の適用を試みた結果，以下のこ 
とがわかった。電極界面の変化に反映して $R_{\mathrm{ct}}$ が変化し, マ イグレーションに至る場合は, 発生前に $R_{\mathrm{ct}}$ が徐々に減少 していく傾向がある。よって，交流インピーダンス法で電 荷移動特性值を測定し，それをモニターすることにより， 今回用いた試料に対してもマイグレーションの発生予測が 可能であることがわかった。

\section{謝 辞}

本研究は新エネルギー・産業技術総合開発機構 基盤技 術研究促進事業（民間基盤技術研究支援制度）によって実 施されたものである。

(2003.9.19-受理)

\section{文献}

1) 田中浩和, 平松洋昭, 冞川和博, 植田文崇, 吉原佐知雄, 白整高史：“交流インピーダンス法を用いた鉛フリーはんだ のイオンマイグレーション発生過程の解析”, エレクトロニ クス実装学会誌, Vol. 5, No. 2, p. 188, 2002

2) 藤嶋 昭, 相澤益男, 井上 徹: “電気化学測定法 (上)”, 技報堂出版， 1984

3) 逢坂哲彌, 小山 昇, 大阪武男: “電気化学法応用測定マ ニュアル”, 講談社, 1989 